cover characters and devise tests within the scope of the skilled, trained pharmaceutical chemist without involving experiments upon living animals, so that the pharmaceutical preparation exhibiting the drug shall be both active and uniform.

\section{The Future.}

The annual meeting of the British Pharmaceutical Conference affords a great opportunity for all pharmacists to meet each other on common ground and consider their common interests. Is not the present a period in pharmaceutical history at which it is fitting that all of us whose lot is cast in pharmacy should band together for our common welfare? The demands of the business side of pharmacy are to-day so imperious and so obvious that there is a danger of neglecting what, to my mind, is of primary importance if we are to persist. If I am asked what path should be pointed out for pharmacists to pursue in order that the present condition of affairs may be improved and the outlook for the future made more bright, then I say without doubt that the answer lies in cultivating assiduously the scientific side of pharmacy; in the promotion, encouragement, and assistance of pharmaceutical research; in the improvement of pharmaceutical products; and in keeping pharmacy abreast of advances in chemistry, physiology, bacteriology, vaccine-therapy, and other kindred subjects.

Only by giving first place to the professional side of pharmacy, keeping as distinct as possible the purely business side and declining to mix with pharmacy proper business in things so far removed from drugs as to be derogatory to the calling of pharmacy-only thus will it be possible to maintain and enhance the esteem in which pharmacists are held by their fellowmen, both medical men and laymen, as well as public bodies and Government Departments.

The British Pharmaceutical Conference exists for "the cultivation of pharmaceutical science" and "to maintain uncompromisingly the principle of purity in medicine." Let pharmacists see to it that the conference receive full and generous support, and that no effort be, spared to enable it to carry out these worthy objects. Thus shall pharmacists prosper and pharmacy flourish.

\section{Medical Science and Education.}

$\mathrm{T}$ his wisely eloquent presidential address to the British Medical Association meeting at Camthe head. He began with the claim that the universities, ancient and modern, from Alexandria to Edinburgh, have made the professions, and stated the university ambitions to be building up character, training in clear thinking, and imparting particular knowledge and experience. He confessed, however, that the new universities compare ill with the old in nourishing the imagination. There is need to learn how to teach; there is need for simplification by more blending of details into larger principles; and there is need to beware of letting our teaching stiffen into formulas. Another point, refreshingly illustrated, was the debt of other sciences to medicine, for what impulses have come from medical studies to cytology, to organic chemistry, to bacteriology, and so on, up to philosophy, as the address itself shows. In medical research, as elsewhere, natural observation is yielding more and more to artificial experiment as investigation penetrates from the more superficial to the deeper processes. "The progress of medicine must in large part be endogenous." "Mere observation-Nature's NO. 2647 , VOL. IO5] muarch past-will not count for much now; and as to family histories-well, they vary with each historian." Once more Sir Clifford Allbutt made a plea for the study of the elements and phases of disease in animals and plants - a comparative pathology that would stir the imagination of young workers and save the world from a wastage as unnecessary as it is incalculable. "Yet no one stirs, save to gyrate each in his own little circle. There is no imagination, no organisation of research, no cross-light from school to school, no mutual enlightenment among investigators, no big outlook. . . How blind we are! "After a very severe but timely criticism of psychotherapy-a criticism which is not marked, however, by any lack of appreciation of the fruitfulness of experimental psychology-Sir Clifford Allbutt closed with some discussion of the immediate problems of general practice and preventive medicine. There is inspiration in the whole address (see British Medical Journal, No. 3105 , pp. I-8), not least in its final glimpse of the possibilities before medicine as a social service and international bond.

At the same meeting of the British Medical Association there was an exceedingly important discussion on the place of "preliminary science" in the medical curriculum-a discussion which will lead, we hope, to some highly desirable changes. In his introductory address Sir George Newman indicated several reforms -a quantitative lightening of the curriculum at both ends, a fresh orientation of the preliminary sciences in relation to the training of medical students, but, above all, more biology and.more real biology. "It is the biological outlook and spirit that is required, the capacity 'to see great truths that touch and handle little ones'; for biology, pure and applied, is the most educative, germinative, and dynamic subject in the whole curriculum." Prof. S. J. Hickson em. phasised the value of biological studies in cultivating habits of verification and precision, in preparing the ground for subsequent anatomical and physiological studies, and in introducing the student to practically important sets of facts, either very concrete as in the case of parasites and their carriers, or more theoretical as in the case of heredity. $\mathrm{He}$ recommended a reduction in the number of "types " so as to make room for more important studies, better orientation of what is taught, and more emphasis on fundamental questions-admittedly difficult as it is to handle them well in teaching beginners. Prof. A. Keith urged that "anatomy could be made a living, practical part of medicine if only the teacher would ask himself : Could this fact help me in diagnosis and treatment?" Sir Ernest Rutherford, speaking of physics, insisted on the necessity for a sound training in the fundamental methods and principles of the science before the medical curriculum is begun, and for a subsequent professional course oriented in a judicious way to future studies in physiology and the like. Prof. Lorrain Smith laid emphasis on the fundamental value of the preliminary sciences as a training in method and criticism, but maintained that the general introduction at present supplied is wasteful in its 'discontinuity with what follows later. It misses part of its aim because its bearings on more professional studies are not made clear. Prof. A. Smithells, speaking of chemistry, indicated some ways in which more value could be got out of the present opportunities if there were more adjustment to the particular ends in view. In general, there seemed to be agreement (see British Medical Journal, No. 3105, pp. 8-2r) on two points: (I) The need for making sure of a firmer grasp of principles, and (2) the need for a re-orientation of the class-teaching in relation to the particular needs of the medical student. 